\title{
DISCRETE COSINE TRANSFORM UNTUK IDENTIFIKASI CITRA HYLOCEREUS COSTARICENSIS
}

\author{
Resty Wulanningrum \\ Fakultas Teknik, Program Studi Teknik Informatika \\ UniversitasNusantara PGRI Kediri \\ Email: resty0601@gmail.com \\ Nandha Vera Wihra Lelitavistara \\ Fakultas Teknik, Program Studi Teknik Informatika \\ UniversitasNusantara PGRI Kediri \\ Email: ve.lelitavistara@gmail.com
}

\begin{abstract}
ABSTRAK
Pengolahan citra digital memiliki peranan sangat luas terhadap kehidupan sehari- hari. Salah satunya dapat digunakan untuk mengidentifikasi citra buah untuk mengetahui tingkat kematangan buah tersebut. Pada penelitian ini identifikasi citra tersebut diterapkan pada hylocereus costaricensis(buah naga merah). Seringkali ketika membeli buah tersebut setelah dimakan daging buah naga terasa sangat lunak dan hambar. Padahal pada buah naga tersebut mengandung rasa manis, asam serta segar.Pada penelitian ini menggunakan metode Discrete Cosine Transform (DCT) dengan objek buah naga merah di kebun buah naga Ngunut, Tulungagung. Citra buah naga dilakukan tahap pre- processing yaitu grayscale dan deteksi tepi, kemudian dilanjutkan pada tahap metode DCT dan pengenalan menggunakan euclidean distances.Penelitian dilakukan dengan pengambilan gambar dari masing- masing tingkat kematangan yang berbeda yaitu pada tingkat kematangan 25\%, 40\%, 60\%, 75\%, dan 90\%. Dari masing- masing sampel dilakukan pengambilan gambar dengan background warna putih. Hasil dari penelitian ini adalah citra buah naga merah mampu diidentifikasi menggunakan DCT dan Euclidean Distance dengan prosentase akurasi sebesar $80 \%$. Besarnya tingkat akurasi dipengaruhi oleh banyaknya jumlah data training yang digunakan.
\end{abstract}

Kata kunci: DCT, deteksi tepi, euclidean distances, grayscale, hylocereus costaricensis.

\begin{abstract}
Digital image processing has a very broad role for daily life. One of them can be used to identify the image of the fruit to determine the maturity level of the fruit. In this study, the identification of the image is applied to the Hylocereuscostaricensis (red dragon fruit). Often when buying the fruit after the edible flesh dragon fruit was very soft and tasteless. Though the dragon fruit contains sweet, sour and fresh.In this study, using Discrete Cosine Transform (DCT) with the object of a red dragon fruit in the gardens dragon fruit Ngunut, Tulungagung. Image of dragon fruit carried out pre-processing stage is grayscale and edge detection, then resumed at the stage DCT and recognition method using euclidean distances. Research carried out by taking pictures of each of the different levels of maturity that is the maturity level of 25\%, 40\%, 60\%, 75\% and 90\%. Of each sample is done taking pictures with white background. Results from this study is the image of a red dragon fruit is able to be identified using the DCT and Euclidean Distance with accuracy percentage of $80 \%$. The level of accuracy is affected by the large number of training data used.
\end{abstract}

Keywords: DCT, edge detection, euclidean distance, grayscale, hylocereuscostaricensis.

\section{PENDAHULUAN}

\subsection{Latar Belakang}

Saat ini masyarakat juga sudah tidak asing lagi dengan hylocereus costaricensis(buah naga merah), yang dapat ditemukan di pasar maupun swalayan. Namun kadang pernah kita temui ketika membeli buah naga merah tersebut setelah dimakan tidak ada rasa dari daging buah naga tersebut, yang ada hanya rasa hambar pada daging buah tersebut. Padahal buah naga tersebut mengandung rasa manis dan asam, sehingga munculah pertanyaan, mengapa pada buah naga tersebut kadang terasa hambar tidak ada rasa manis maupun asam, dan apakah hal itu dikarenakan buah naga masih belum matang?

Dari hal tersebut penulis akan melakukan sebuah penelitian untuk mengidentifikasi tingkat kematangan pada buah naga merah yang bertujuan mengukur berapa tingkat kematangan pada buah naga tersebut. Tingkat 
kematangan pada buah naga tersebut dapat diidentifikasi dengan melakukan pengembangan Red Green Blue (RGB) pada citra objek yaitu buah naga merah. Serta penerapan metode Discrete Cosine Transform (DCT) untuk mengetahui hasil akurasi dari kematangan buah naga. Sehingga hasil penelitian tersebut akan memudahkan petani buah naga ketika melakukan sortir buah naga setelah dipanen dan sebelum didistribusikan.

\subsection{Batasan Masalah}

Batasan masalah pada penelitian, yaitu:

1. Objek buah naga yang digunakan pada penelitian ini yaitu varietas buah naga merah (Hylocereus Costaricensis) dengan kondisi buah normal/ sehat serta penelitian dilakukan di Desa Ngunut, Kecamatan Ngunut, Kabupaten Tulungagung.

2. Analisis pengolahan citra pada objek buah naga merah menggunakan analisis perubahan warna yang terjadi atau unsur RGB serta menggunakan metode DCT untuk mengetahui hasil akurasi dari kematangan buah naga merah.

3. Menggunakan perangkat lunak pendukung Delphi7 serta citra objek dengan dimensi ukuran piksel 120 x 120 .

\subsection{Rumusan Masalah}

Rumusan masalah pada penelitian, yaitu:

1. Bagaimana mengetahui tingkat kematangan serta kelayakan buah naga merah pada proses sortir sebelum didistribusikan?

2. Bagaimana mengimplemintasikan metode DCT untuk mengidentifikasi kematangan buah naga merah berdasarkan perubahan warna atau RGB serta menghasilkan akurasi nilai kematangan buah naga merah tersebut?

3. Bagaimana penerapan perangkat lunak pendukung untuk implementasi metode DCT dan analisis RGB, serta pengambilan citra objek pada penelitian ini?

\subsection{Landasan Teori}

\subsubsection{Buah Naga}

Buah Naga memiliki beberapa spesies buah yang berbeda, klasifikasi buah naga termasuk kelompok tanaman kaktus atau familyCactaceae dan subfamily Hylocereanea. Varietas buah naga sejauh ini dibedakan kedalam empat grup berdasarkan warna buah, yaitu buah naga daging putih (Hylocereus undatus), buah naga daging merah (Hylocereus. polyrhizus), buah naga daging super merah (Hylocereus costaricensis), dan buah naga kulit kuning daging putih (Selenicerius megalanthus). [1]

Tanaman buah naga mempunyai batang sulur yang tumbuh menjalar, berwarna hijau dengan bentuk segi tiga. Bunganya berukuran besar, berwarna putih-kuning muda, dan mekar umumnya di malam hari. Setelah bunga layu maka terbentuk bakal buah yang menggelantung disetiap batang.[1]

\subsubsection{Grayscale}

Grayscale juga disebut dengan tingkat keabuan. Grayscale merupakan tahap dari pre-processing yang digunakan untuk mempersiapkan citra agar dapat menghasilkan ciri yang lebih baik pada tahap pemisahan ciri. [2]

Pada umumnya warna yang digunakan pada grayscale adalah warna hitam sebagai warna minimal (0), dan warna putih (255) sebagai warna maksimal, sehingga warna antaranya adalah abu-abu. Derajat keabuan sendiri memiliki nilai, tidak hanya skala 0 sampai 255. Tergantung pada nilai piksel yang dimiliki oleh citra[3]. Adapun untuk tingkat keabuan ditunjukkan oleh gambar 1.

Rumus dari Grayscale $G=\left(\frac{R+G+B}{a}\right)$

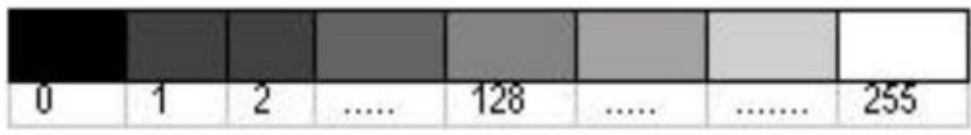

Gambar 1. Tingkat Keabuan Pada Grayscale [4] 


\subsubsection{Deteksi Tepi}

Deteksi tepi (Edge Detection) pada suatu citra adalah suatu proses yang menghasilkan tepi-tepi dari obyekobyek citra, tujuannya adalah :

a. Untuk menandai bagian yang menjadi detail citra

b. Untuk memperbaiki detail dari citra yang kabur, yang terjadi karena error atau adanya efek dari proses akuisisi citra.[5]

Pada deteksi tepi terdapat bermacam- macam metode, yang sering digunakan yaitu metode Robert, Prewitt dan Sobel.Metode Sobel merupakan pengembangan metode robert yang diberi satu angka nol penyangga. Metode ini mengambil prinsip dari fungsi laplacian dan gaussian. Kelebihan dari metode sobel ini adalah kemampuan untuk mengurangi noise sebelum melakukan perhitungan deteksi tepi. Matriks yang digunakan pada metode Sobel ini adalah [5]:

$$
\mathrm{H}=\left[\begin{array}{lll}
-1 & 0 & 1 \\
-2 & 0 & 2 \\
-1 & 0 & 1
\end{array}\right]
$$

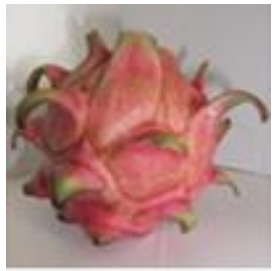

Gambar 2. Sebelum Deteksi Tepi
$\mathrm{V}=\left[\begin{array}{ccc}-1 & -2 & -1 \\ 0 & 0 & 0 \\ 1 & 2 & 1\end{array}\right]$

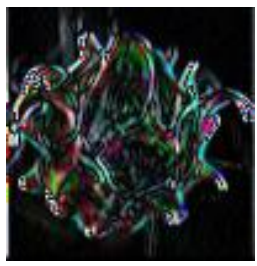

Gambar 3. Setelah Deteksi Tepi

\subsubsection{Discrete Cosine Transform}

Discrete Cosine Transform (DCT) merupakan salah metode yang digunakan dalam pengolahan citra untuk proses kompresi citra. Sedangakan pendapat lain dari definisi DCT yaitu menurut Kartika Retno Mustikaningpuri, Asep Juarna (2009), yaitu "Discrete Cosine Transform (DCT) merupakan algoritma lossy image compression sebagai bakuan untuk citra JPEG”. DCT mempunyai dua sifat utama untuk kompresi citra dan video yaitu:

1. Mengkonsentrasikan energi citra ke dalam sejumlah kecil koefisien (energi compaction).

2. Meminimalkan saling ketergantungan diantara koefisien-koefisien (decorrelation).

Sifat dari DCT adalah mengubah informasi citra yang signifikan dikonsentrasikan hanya pada beberapa koefisien DCT. Oleh karena itu DCT sering digunakan untuk kompresi citra seperti pada JPEG dengan aslinya tanpa cacat. [6]. Kelebihan kompresi data menggunakan Discrete Cosine Transform adalah:

1. DCT menghitung kuantitas bit-bit data gambar dimana pesan tersebut disembunyikan didalamnya. Sehingga tidak akan ada perubahan yang terlihat pada cover gambar, dan

2. Kokoh terhadap manipulasi pada stego-object.

Kekurangan kompresi data menggunakan Discrete Cosine Transform adalah:

1. Tidak tahan terhadap perubahan suatu objek dikarenakan pesan mudah dihapus karena lokasi penyisipan data dan pembuatan data dengan metode DCT diketahui.

2. Implementasi algoritma yang panjang dan membutuhkan banyak perhitungan.

$$
\sum_{\mathrm{I}=0}^{\mathrm{N}-1} \sum_{\mathrm{j}=0}^{\mathrm{M}-1} \mathrm{I} \frac{\mathrm{CuCv}}{\sqrt{\mathrm{MN}}}
$$

Pada makalah ini penulis akan menggunakan perhitungan DCT- 2D. DCT- 2D merupakan perbandingan dari DCT-1D, maka transformasi diskrit dapat dinyatakan dalam bentuk persamaan. Dalam algoritma JPEG, sampel gambar I(i , j) dibagi menjadi blok 8x8. Setiap blok ditransformasi menjadi 8x8 matriks koefisien DCT. Menurut Nadia Printa Tearani (2014) definisi matematis dari masing-masing blok koefisien didefinisikan sebagai berikut:

$d_{u, v}=\frac{\operatorname{CuCv}}{\sqrt{\mathrm{MN}}} \sum_{\mathrm{i}=0}^{\mathrm{N}-1} \sum_{\mathrm{j}=0}^{\mathrm{M}-1} \mathrm{I} \mathrm{i} . \mathrm{j} \cos \left(\frac{(2 \mathrm{i}+1) \mathrm{u} \pi}{2 \mathrm{~N}}\right) \cos \left(\frac{(2 \mathrm{j}+1) v \pi}{2 \mathrm{M}}\right)$

dengan $u=0,1,2, \ldots, n-1$, dan $v=0,1,2, \ldots, m-1$. 
Rumus DCT- 2D diatas sering juga disebut sebagai forward discrete cosine transform (FDCT). Nilai konstanta basis fungsi yang terletak di bagian kiri atas sering disebut sebagai basis fungsi DC, dan DCT koefisien yang bersesuaian dengannya disebut sebagai koefisien DC (DC coefficient). Dan hasil dari rumus DCT- 2D tersebut kemudian diperoleh fungsi basis DCT- 2D.

$$
C(i, j, u, v)=\frac{2}{\sqrt{M N}} \cos \left(\frac{(2 i+1) w \pi}{2 N}\right) \cos \left(\frac{(2 j+1) v \pi}{2 M}\right)
$$

dengan nilai $u$ dan $i=0,1,2, \ldots, N-1$, sedangkan $v$ dan $j=0,1,2, \ldots, M-1$.

\subsubsection{Euclidean Distances}

Euclidean distance merupakan salah satu metrika yang digunakan untuk mencocokan dua vector. Menurut Darma Putra (2009) fungsi dari metrika pencocokan adalah sebagai berikut:

"Metrika pencocokan digunakan untuk menentukan tingkat kesamaan (similarity degree) atau ketidaksamaan (dissimilarity degree) dua vector. Tingkat kesamaan berupa suatu skor dan berdasarkan skor tersebut akan dikatakan mirip atau tidak."

Euclidean distance (jarak Euclidean) dirumuskan dengan menghitung akar dari kuadrat perbedaan dua vector. [2]

Rumus jarak Euclidean:

$d_{i j}=\sqrt{\sum_{k=1}^{n}\left(x_{i j}-x_{j k}\right)^{2}}$

\section{METODOLOGI PENELITIAN}

Metodologi penelitian ini terlihat seperti pada gambar 4 flowchart sistem.

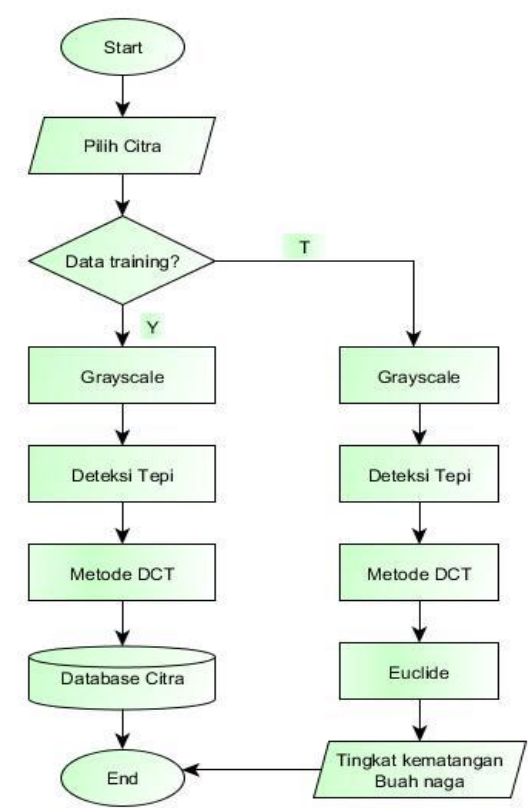

Gambar 4. Flowchart Sistem

Penjelasan dari gambar 4 flowchart sistem sebagai berikut: Pada tahap awal adalah pemilihan citra, apakah termasuk citra training, jika benar maka akan dilakukan proses grayscale. Proses grayscale merupakan proses perubahan citra berwarna menjadi keabu- abuan. Maksud dari penggunaan grayscale ini adalah untuk menormalisasi nilai dari citra tersebut. Setelah citra menjadi keabu- abuan, selanjutnya dilakukan deteksi tepi menggunakan operator sobel. Selanjutanya dilakukan kompresi citra menggunakan metode Discrite Cosine Transform(DCT). Pada data training, citra tersebut akan disimpan pada database dan pada data testing dilakukan perhitungan Euclidean Distance. Penghitungan jarak Euclidean ini maksudnya adalah mencari jarak antara citra training dengan citra testing. Jarak tersebut digunakan untuk pengenalan citra buah naga merah dengan tingkat kematangan yang sesuai. 


\section{HASIL PENELITIAN}

Hasil implementasi merupakan tahap penerapan konsep serta metode yang digunakan pada aplikasi yang akan dibuat. Berikut merupakan tampilan program yang telah dibuat.

1. Tampilan Data training

Tampilan data training dari aplikasi pengenalan citra buah naga digunakan untuk proses training data. Maksudnya adalah, data yang dilakukan pelatihan (training) kemudian akan disimpan dialam database. Adapun tampilan aplikasi untuk citra training terlihat pada gambar 5 .

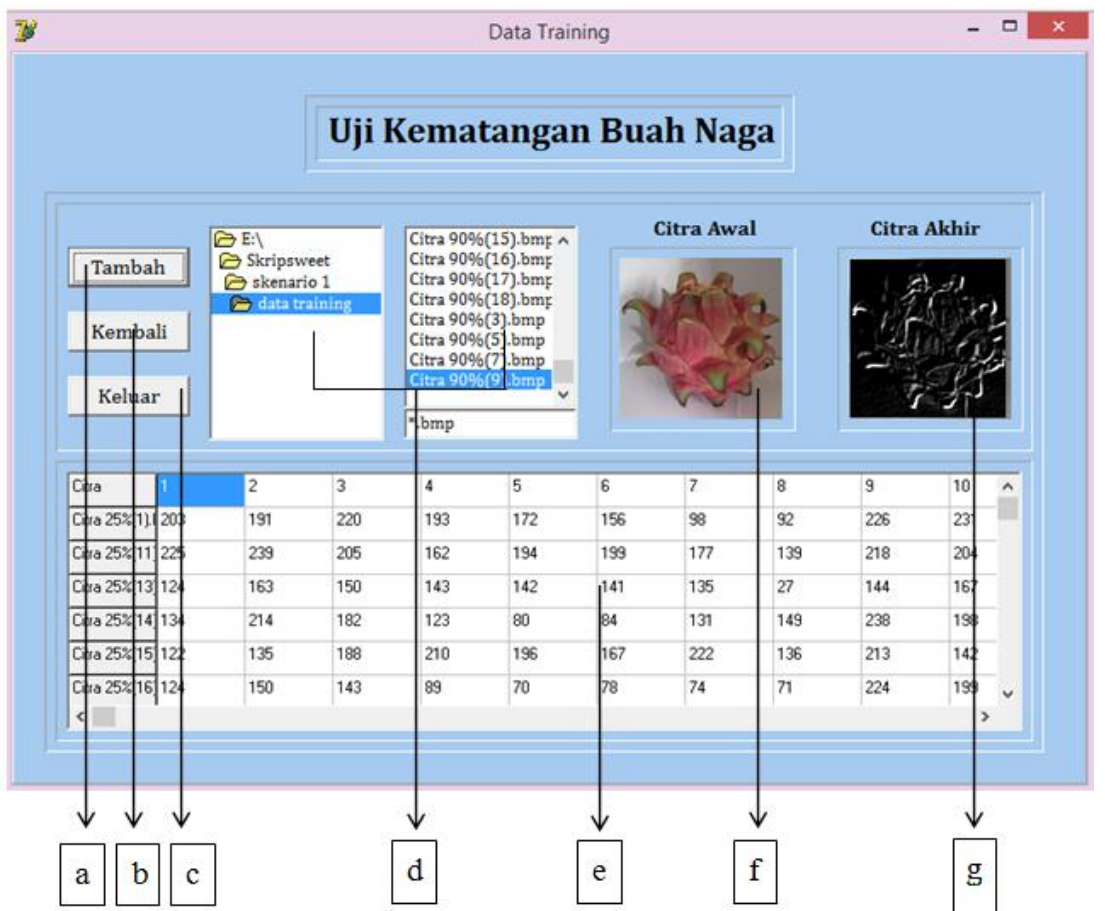

Gambar 5. Tampilan Form Data Training

Keterangan dari gambar tersebut adalah sebagai berikut:

a. Tombol Tambah

Berfungsi untuk memasukkan gambar yang akan disimpan di database.

b. Tombol Kembali

Berfungsi untuk kembali di menu utama.

c. Tombol Keluar

Berfungsi untuk keluar dari program.

d. Directory List Box dan File List Box

Directory list box berfungsi untuk menampilkan folder dimana citra disimpan, sedangkan file list box menampilkan nama file yang disimpan di dalam folder.

e. String Grid Database Citra

Berfungsi sebagai database untuk menampung nilai piksel gambar.

f. Image Preview Citra Awal

Berfungsi untuk menampilkan gambar dari citra yang dipilih.

g. Image Preview Citra Akhir

Berfungsi untuk menampilkan gambar dari citra yang sudah mengalami proses pengolahan citra dan metode DCT.

2. Tampilan Data Testing

Tampilan data testing disini dimaksudkan untuk uji coba citra buah naga merah. Citra testing (uji coba) akan dicari jarak kedekatannya dengan citra training yang ada pada database. Untuk mencari jarak kedekatannya menggunakan Euclidean distance. Tampilan data testing diperlihatkan oleh gambar 6. 


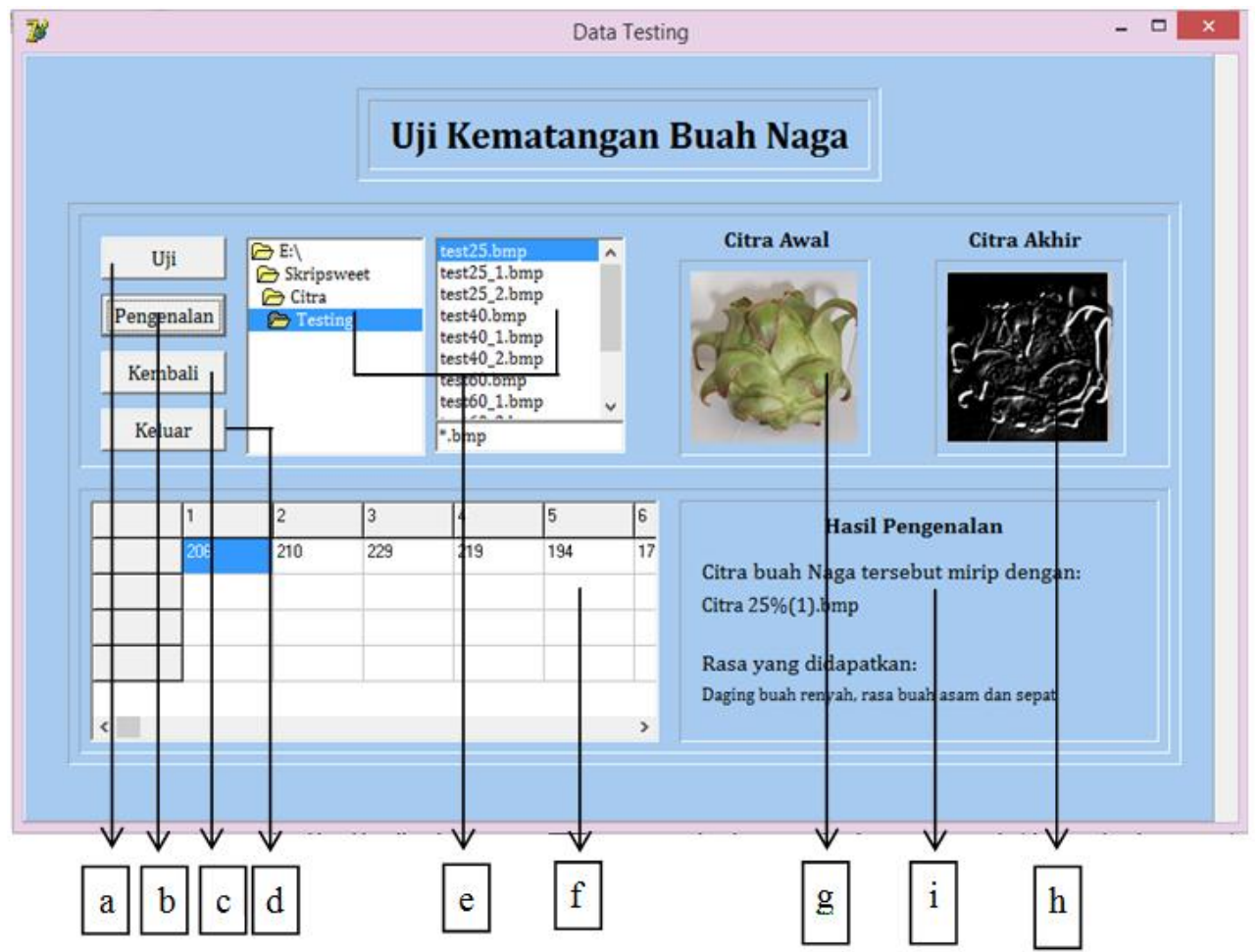

Gambar 6. Tampilan Form Data Testing

Keterangan dari gambar tersebut adalah sebagai berikut:

a. Tombol Uji

Berfungsi untuk mengeksekusi gambar yang telah dipilih.

b. Tombol Pengenalan

Berfungsi untukmengetahui hasil pengenalan dari buah naga yang telah di uji.

c. Tombol Kembali

Berfungsi untuk kembali di menu utama.

d. Tombol Keluar

Berfungsi untuk keluar dari program.

e. Directory List Box dan File List Box

Directory list box berfungsi untuk menampilkan folder citra disimpan, dan file list box untuk menampilkan nama file di dalam folder tersebut.

f. $\quad$ String Grid Database Citra

Berfungsi sebagai database untuk menampung nilai piksel gambar.

g. Image Preview Citra Awal

Berfungsi untuk menampilkan gambar dari citra yang dipilih.

h. Image Preview Citra Akhir

Berfungsi untuk menampilkan gambar dari citra yang sudah mengalami proses pengolahan citra dan metode DCT.

i. Hasil Pengenalan

Berfungsi untuk menampilkan hasil pengenalan dari citra yang telah di uji.

Pada evaluasi sistem data uji coba yang dibutuhkan yaitu sampel citra dari tingkat kematangan buah naga merah yang berbeda yaitu 25\%, 40\%, 60\%, 75\% dan 90\%. Untuk citra buah naga dengan kematangan yang akan diuji coba diperlihatkan pada gambar 7 . 

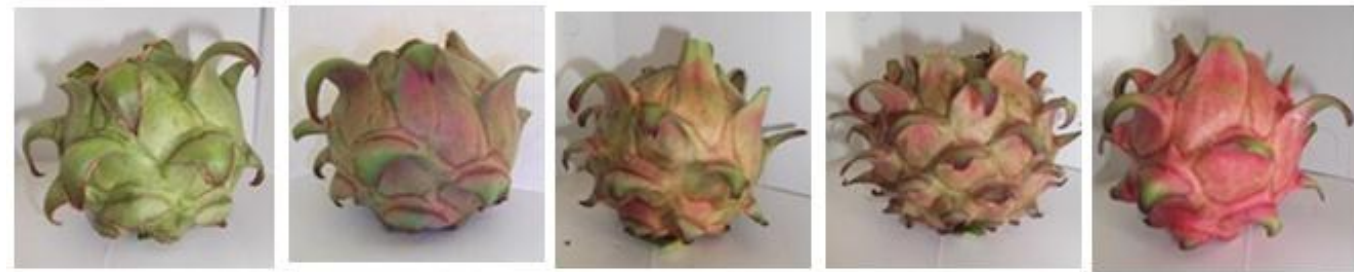

\section{Gambar 7. Sampel Buah Naga Merah Pada Tingkat Kematangan Yang Berbeda}

Dalam proses uji coba, digunakan scenario uji coba untuk mendapatkan hasil yang terbaik. Ada 4 macam scenario yang digunakan pada data training, yaitu scenario yang pertama data yang digunakan sebanyak 12 data, scenario yang kedua sebanyak 9 data, scenario yang ketiga sebanyak 6 data dan scenario yang keempat sebanyak 3 data. Scenario detailnya diperlihatkan pada table 1.

Tabel 1. Data training

\begin{tabular}{|c|c|c|c|c|c|c|}
\hline \multirow{2}{*}{ No } & \multicolumn{5}{|c|}{ Data Training } & \multirow{2}{*}{ Jumlah } \\
\hline & Tingkat 25\% & Tingkat 40\% & Tingkat 60\% & Tingkat 75\% & Tingkat 90\% & \\
\hline 1 & $\begin{array}{c}1,2,3,4,5,6, \\
7,8,9,10,11, \\
12\end{array}$ & $\begin{array}{c}1,2,3,4,5,6 \\
7,8,9,10,11 \\
12\end{array}$ & $\begin{array}{c}1,2,3,4,5,6 \\
7,8,9,10,11 \\
12\end{array}$ & $\begin{array}{c}1,2,3,4,5,6 \\
7,8,9,10,11 \\
12\end{array}$ & $\begin{array}{c}1,2,3,4,5,6, \\
7,8,9,10,11, \\
12\end{array}$ & 60 \\
\hline 2 & $\begin{array}{c}1,2,3,4,5,6, \\
7,8,9\end{array}$ & $\begin{array}{c}1,2,3,4,5,6 \\
7,8,9\end{array}$ & $\begin{array}{c}1,2,3,4,5,6 \\
7,8,9\end{array}$ & $\begin{array}{c}1,2,3,4,5,6 \\
7,8,9\end{array}$ & $\begin{array}{c}1,2,3,4,5,6 \\
7,8,9\end{array}$ & 45 \\
\hline 3 & $1,2,3,4,5,6$ & $1,2,3,4,5,6$ & $1,2,3,4,5,6$ & $1,2,3,4,5,6$ & $1,2,3,4,5,6$ & 30 \\
\hline 4 & $1,2,3$ & $1,2,3$ & $1,2,3$ & $1,2,3$ & $1,2,3$ & 15 \\
\hline
\end{tabular}

Ada 4 macam scenario yang digunakan pada data testing, yaitu scenario yang pertama data yang digunakan sebanyak 2 data, scenario yang kedua sebanyak 3 data, scenario yang ketiga sebanyak 4 data dan scenario yang keempat sebanyak 5 data. Scenario detailnya diperlihatkan pada table 2.

Tabel 2. Data testing

\begin{tabular}{clccccc}
\hline \multirow{2}{*}{ No } & \multicolumn{5}{c}{ Data Testing } & \multirow{2}{*}{ Jumlah } \\
\cline { 2 - 6 } & Tingkat 25\% & Tingkat 40\% & Tingkat 60\% & Tingkat 75\% & Tingkat 90\% & \\
\hline 1 & 1,2 & 1,2 & 1,2 & 1,2 & 1,2 & 10 \\
2 & $1,2,3$ & $1,2,3$ & $1,2,3$ & $1,2,3$ & $1,2,3$ & 15 \\
3 & $1,2,3,4$ & $1,2,3,4$ & $1,2,3,4$ & $1,2,3,4$ & $1,2,3,4$ & 20 \\
4 & $1,2,3,4,5$ & $1,2,3,4,5$ & $1,2,3,4,5$ & $1,2,3,4,5$ & $1,2,3,4,5$ & 25 \\
\hline
\end{tabular}

Tabel 3. Hasil akurasi sistem

\begin{tabular}{cccccc}
\hline \multirow{2}{*}{ Skenario } & \multicolumn{2}{c}{ Data } & \multicolumn{2}{c}{ Hasil } & \multirow{2}{*}{ Prosentase } \\
\cline { 2 - 5 } & Training & Testing & Salah & Benar & \\
\hline I & 60 & 10 & 2 & 8 & $80 \%$ \\
II & 45 & 15 & 6 & 9 & $60 \%$ \\
III & 30 & 20 & 10 & 10 & $50 \%$ \\
IV & 15 & 25 & 13 & 12 & $48 \%$ \\
\hline
\end{tabular}

Dari hasil implementasi program aplikasi dengan menggunakan data pada tabel 3 tersebut maka adapun hasil akurasi program sangat dipengaruhi oleh besar kecilnya nilai pada data training Selain itu dataset yang digunakan pada penelitian ini merupakan citra dari buahnagamerah pada masing- masing tingkat kematangan yang ditentukan berdasarkan warnakulitbuah, sehingga pengambilan objek gambar serta warna dari gambar tersebut akan berpengaruh besar terhadap hasil pengenalan buah. 


\section{KESIMPULAN}

Berdasarkan hasil uji coba diatas maka dapat disimpulkan:

1) Metode DCT dapat digunakan untuk mengidentifikasi citrabuahnagamerahguna mengetahui tingkat kematanganbuahnaga tersebut..

2) Implementasi metode DCT serta euclidean distance dapat menunjukkan hasil pengenalan dari masing- masingbuahnaga. Dan prosentase akurasi yang didapatkan yaitu $80 \%$ dengan perbandingan data training dan data testing sebanyak $60: 10$, prosentase akurasi $60 \%$ dengan perbandingan data training dan data testing sebanyak 45:15, prosentase akurasi $50 \%$, dengan perbandingan data training dan data testing sebanyak 30:20, dan prosentase akurasi 48\%, dengan perbandingan data training dan data testing sebanyak 15:25. Sehingga besarnya tingkat akurasi dipengaruhi oleh banyaknya data training yang digunakan.

Penerapan perangkat lunak pendukung Delphi7 serta citra objek dengan dimensi ukuran piksel $120 \mathrm{x}$ 120 untuk implementasi metode DCT dan analisis RGB dapat berjalan dengan baik serta mendapatkan hasil yang maksimal.

\section{DAFTAR PUSTAKA}

[1] Renasari. Novita. (2010). Budidaya Tanaman Buah Naga Super Red Di Wana Bekti Handayani. (Online). tersedia: http://eprints.uns.ac.id/308/1/ 158172408201011401.pdf. diunduh 9 Nopember 2014.

[2] Putra. Darma. (2009). Sistem Biometrika. Yogyakarta: ANDI.

[3] Nazaruddin. Ahmad. (2013). Pengolahan Citra Digital (Digital Image Processing). (Online). tersedia: http://nazaruddin.blog.unigha.ac.id/wp-content/ uploads/sites/3/PCD-02.pdf, diunduh 25 Maret 2014.

[4] Achmad. Ir. Balza. (2005). Teknik Pengolahan Citra Digital menggunakan DELPHI. Yogyakarta: Ardi Publishing.

[5] Riyanto. (2008). Deteksi Tepi (Edge Detection), (Online). tersedia: http://riyanto.lecturer.pens.ac.id/citra-bab8.pdf, diunduh 2 Juli 2015.

[6] Mustikaningpuri, K. R., et al. (2009). Kompresi Citra Jpeg Berbasis Metode Dct (Discrete Cosinus Transform), 24 (1).(Online). tersedia: http://hdl.handle.net/123456789/7014.diunduh14 Nopember 2014.

[7] Tearani. N.P. (2014). Peningkatan Kompresi Citra Digital Menggunakan Discrete Cosine Transform - 2 Dimension(DCT - 2D). (Online). tersedia: http://eprints.dinus.ac.id/id/eprint/5388. diunduh 14 Nopember 2014. 